\title{
Impact of tensile strength and elongation on bursting strength of mulberry silk/viscose blended knitted fabrics
}

Received: 31.07.2018; Revised: 04.04.2019; Accepted: 13.04 .2019

See end of the paper for authors' affiliations

\section{Shikha Bajaj}

Department of Apparel and

Textile Science, College of Home

Science, Punjab Agricultural

University, Ludhiana (Punjab)

India

Email : shikhabajaj26@

gmail.com
ABSTRACT : The bursting behaviour of mulberry silk / viscose blended knitted fabrics has been tested and its relationship with tensile strength and elongation has been analyzed. Bursting strength is an important characteristic for any knitted fabric. Stress is applied from all the directions to test the fabric. For the present study, mulberry silk /viscose blended knitted fabrics were developed in two unlike counts, by using weft knitting process and were subjected to bursting strength test. An investigation has been made of two alleged variables of bursting strength viz., tensile strength and elongation of fabric and their relationship with bursting strength was analyzed using regression analysis. Statistical computations were carried out using SPSS 20 package. It was confirmed by calculation and comparison that tensile strength was a firm contributor to bursting strength with regression co-efficient of 0.038 in wale wise direction and 0.027 in course wise direction, however, a feeble but negative relationship was seen in case of elongation percentage and bursting strength with regression co-efficient of 0.106 in wale wise direction and -0.038 in course wise direction.

GEY WORDS: Bursting, Elongation, Fabric, Strength, Tensile

- HOW TO CITE THIS PAPER : Bajaj, Shikha and Bains, Sandeep (2019). Impact of tensile strength and elongation on bursting strength of mulberry silk/viscose blended knitted fabrics. Asian J. Home Sci., 14 (1) : 22-27, DOI: 10.15740/HAS/AJHS/14.1/22-27. Copyright@ 2019: Hind Agri-Horticultural Society. 